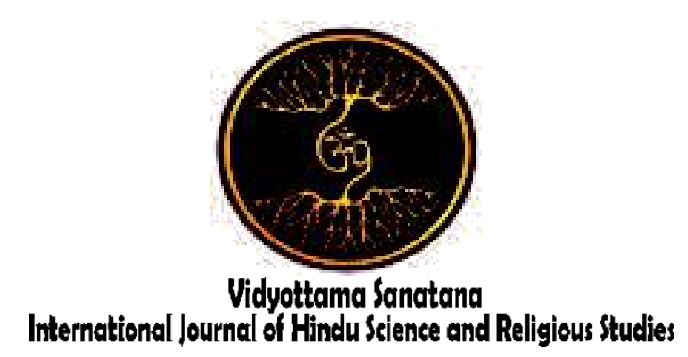

Vol. 2 No. 2 October 2018

\title{
Salunglung Sabayan Taka: \\ The Balinese Behavior in Toraja Translating the Original Culture
}

\author{
By: \\ David Samiyono ${ }^{1}$, I Made Suardana ${ }^{2}$ \\ ${ }^{1}$ Satya Wacana Christian University, Salatiga, Central-Java, Indonesia \\ ${ }^{2}$ Sekolah Tinggi Agama Kristen Negeri, Toraja. \\ E-mail: d_samiyono@yahoo.com
}

Received: August 20, 2018

Accepted: September 5, 2018

Published: October 31, 2018

\begin{abstract}
This study aims to gain a deeper description of the cultural behavior of Balinese immigrants in Toraja in their encounter with local wisdom depicted the philosophy of "Salunglung Sabayantaka". From this study, it can be concluded that the philosophy of "Salunglung Sabayantaka" is still fundamental to the living habits of the Balinese although the life in the overseas ie Toraja which is detached from the ties of the pekraman village in Bali, as well as the bonds of their respective belief values.

The basic principles of the sabayantaka scroll that should be bound in the integrity of the custom village or the pekraman village have not undergone the significant changes in the fulfillment of life responsibilities, especially in their encounters with community life and local wisdom. The Balinese community in Toraja have been working on the behavior of salunglung sabayantaka life regardless the differences in beliefs and culture. The behavioral content of life is an evident in the presence of Balinese society in supporting the social responsibilities of the community in Toraja, in applying the example of salawatlung sabayantaka life and in educating the family as well as in society. The Balinese Mentality in Toraja, in relation to the philosophy of "Salunglung Sabayantaka" is the manifestation of the behavior of educating children measurably in placing the child as a whole part of family life, society and culture. This research will be a reference to build the living habits of the immigrant Balinese people in Toraja in their encounter with local wisdom, so that the Balinese cultural behavior in Toraja still supports the philosophy of "Salunglung Sabayantaka", so that every Balinese society in Toraja is definitely changing according to the dynamics of the society development. It continues to build the social contacts based on the combination of cultures that make up their cultural strengths.
\end{abstract}

Keywords: Salunglung sabayantaka, Balinese People, Culture, Religion and education. 


\section{Introduction}

The rhythm of human consciousness to solve each other's life problems is a vast space within which various approaches and behavioral order are formed to respond to the various needs of human beings without abandoning the essence of human beings who are bound to each other. The formation of behavior in society is the evidence of the cultural dynamics implementation that "incarnate" as a cultural tool in various symbols and habits form in a society. The habits of a society are a reflection of the cultural behavior of the community. Understanding the popularized habits can not be separated from the values of life which are appreciated in various forms. The philosophy of Salunglung Sabayan Taka that is lived by the Balinese people is also the value of life that is always strived to form the order of life in various responsibilities and become a habit that has blended with the Balinese. It can be interpreted as an effort to actualize themselves in the various interests and necessities of life of the Balinese people. The fundamental point of a habit as a cultural behavior is reflected in the extent to which these behaviors build people's lives and form a mutually empowering, educating, and managing life as the existing resources.

Society in general, including the Balinese people live in habits that have been rooted in the community life. Various habits of life are of course very closely related to the achievements of life in the community. Balinese people are identical with the philosophy of "Salulung Sabayan Taka". The philosophy has become a wholeness of selfbuilding responsibility. The philosophy of "Salulung Sabayan Taka" is a moral teaching of society that has been lived for generations as a cultural heritage. The philosophy of life "Salulung Sabayan Taka" is an integral part of the cultural integrity of the Balinese called Trihitakarana. Tri means 'three'; hita means 'goodness / happiness'; karana means 'cause'. It means there are three things that will cause good or happy human life. Those three things are: First, Parhyangan: a harmonious and balanced relationship between man and God, or more clearly explanation is, the obedience of the devoted man and the implementation of the religious teachings. Second, Pawongan: a harmonious and balanced relationship between human beings, which means fostering harmony, friendship, tolerance, mutual respect, mutual help, mutual cooperation, and mutual reminders. This condition is subsequently expressed in the philosophy of Bali as Sagilik saguluk salunglung sabayantaka, paros paros sarpanaya, saling asah, saling asih, saling asuh. The translation is : united in sorrow and deal with dangers, have discussion and have deliberation (appreciate others' opinions), remind each other, love each other, and help each other. Third, Palemahan: a harmonious and balanced relationship between man and nature. This means that humans should maintain and preserve the universe, because human life depends on nature. When humans destroy the nature then in turn, the nature will also destroy humans. The source of inspiration Tri Hita Karana comes from the Holy Book of Hindu Religion known by the name: Bhagawad Gita. In terms of etymology Tri Hita Karana comes from the word Tri which means three, Hita means good, happy, cheerful, sustainable, and Karana means causation, or the source of the cause. Thus Tri Hita Karana means three elements that are the source of the cause that allows the emergence of goodness. Tri Hita Karana comes into contact with the element of pawongan, serves as a social subsystem, and as a place for interaction in rights and obligations. Tri Hita Karana is also based on the spirit of mutual cooperation which reflects the existence of balanced pattern and harmony relationship.

Real cultural behavior by itself becomes the unity of life as a form of behavior to resolve the problem of life itself. The Balinese generally live in a variety of moral orders born out of the Balinese people's struggle, then synergize in selfappreciation and achievement of their lives, as well as in providing education for the next generation. In terms of reviving its cultural 
values, the reality of Balinese society will be very different when they live in different tribal societies as well as in the different context of customs and cultures.

To revive the philosophy of "Salulung Sabayan Taka" in establishing the self-righteousness of the individual, must be closely related to the values of interdependence in a cultural community. In this case, it is important to answer how do the Balinese revive the philosophy of "Salulung Sabayan Taka" when different cultural values become the reality of Balinese society in local culture? Are in multicultural societies, each local wisdom still maintained and bound throughout the Indonesian people even in different disclosures?

In principle, the values contained in "Salulung Sabayan Taka" put life as a reality of culture, and vice versa, so any process that is done as a form of life accountability as "Salulung Sabayan Taka" is the bond of feeling and working the interdependence, and also become a common consciousness of every culture as a whole life of the nation and state of Indonesia. As an educational reality is the interdependence, then by itself, the educated reality is the fullness of the interdependence of fellow human beings. In the philosophy of "Salulung Sabayan Taka", man becomes very important for his fellow human beings to form educated human beings. Man becomes very meaningful to his neighbor and his environment to create the highest and dignified creatures for life and culture. The Interdependence becomes a necessity for the development and the implementation of science, skills and nobility of life in processing the educated human beings.

How do the Balinese people in particular who live and socialize overseas with the cultural differences can still revive the dynamics of interdependence / togetherness as the actualization of life in "Salulung Sabayan Taka"? This fact is very important to learn as a whole by looking at the actualization of local wisdom which has the same sense but put in different phrases, are able to support the values of outside cultures to stay alive and thrive despite the current conditions with the unlimited technological sophistication, has brought the life of the world community in a "global village". Nevertheless, The world culture is based on the sophistication of mass communication technology across the country without boundaries so that the ethnic presence increasingly blurred, but strong ethnic emotional bonds still survive in kinship even in a more simple and new form which is believed to have deep meaning in building the welfare of their lives. Therefore, there is a need for a more comprehensive study of ethnic presence to respond and actualize the values of life, so that among the various ethnic groups can contribute positively to the improvement of human values and the development of civilized life. Based on the above formulation, the research questions are (1) “ Is the philosophy of Salunglung Sabayantaka still a living habit for the Balinese immigrant Community in Toraja in its encounter with the local wisdom? "And (2) "How does the Balinese Society in Toraja translate the" Salunglung Sabayantaka "Philosophy as a cultural act in Toraja?". Thus the purpose of this study is to illustrate the philosophy of "Salunglung Sabayantaka" in the life of the Balinese immigrant Society in Toraja in its encounter with the local wisdom and also describe the Balinese people's behavior in Toraja in connection with the philosophy of "Salunglung Sabayantaka"

\section{Methods}

The research method used is a qualitative research approach. The qualitative research provides a broad opportunity to describe the phenomenon as it is and also the space to understand holistically the meaning of the phenomenon. The principles which become the fundamental considerations for the qualitative approaches are: 
First, the symptoms studied are more of a dynamic social phenomenon that is about the problem of cultural role, the role of cultured society, and the role of other supporting factors as social dynamics. The basic assumptions laid behind the phenomenon studied are the Balinese community in Toraja which is also as the whole part of the social dynamics of the Balinese society as a whole, which has a dynamic tendency to be active, responsive to all forms of change and also allows the tendency of paradigm shifts that emerge from every development of social and cultural phenomena that exists in the society in Bali and in overseas, especially in Toraja. The actors in this case are the Balinese people of Toraja who are assumed not to be structurally-deterministically directed and / or driven by the developing structure, but they have the freedom (voluntary) to determine their role according to their desires and inclinations without being co-opted by the structure social community in which the Balinese are domiciled. In fact they have the ability to participate in coloring, shaping and directing the social structure.

Secondly, the subject matters in this study are related to the process of a movement which may be indicated by the symptoms of concrete thoughts and actions demonstrated by the Balinese community in Toraja. In this case Creswell (John W. Creswell, 2010: 259) states that the main concern of qualitative researchers is related to the processes that occur rather than the outcomes. Events occurring in the experimental process are understood and given a meaning through an interpretation of both the subject and the researcher. The focus is on more specific situations or societies whose emphasis is on meanings that are interpreted on the basis of the expressions of the informers, not the number of people who are the subject of the study.

The data used by the researcher are observation data, interview, and documentation, then the collected data are analyzed, that is the process of checking and organizing, that is organizing and sequencing the data into the pattern, category and the basic description. This step is done to uncover important meaningful matters, and establish the results of the analysis as a material for withdrawing the substantive theory and or grounded theory. To analyze the data, it is focused on the disclosure of cultural behaviors that are patterned based on the actualization narrative philosophy of "Salunglung Sabayan Taka" in the living habits of the Balinese Immigrant Society in Toraja, in respond to their encounter with local wisdom as well as reading the Balinese community in Toraja, in the wealth of identity in connection with the philosophy of "Salunglung Sabayan Taka ", which is illustrated by: The principle of kinship in the philosophy of" Salunglung Sabayan Taka "; The principle of togetherness in the philosophy of "Salunglung Sabayan Taka"; The principle of wholeness in the philosophy of "Salunglung Sabayan Taka".

Fundamentally, this research provides a clear and firm understanding towards the philosophy of "Salunglung Sabayantaka" in the life of the Balinese Immigrant Community in Toraja and positive implications for the development of social theories based on local wisdom. It can be used as a reference for scientific development in the field of developed social approach based on the values of local wisdom. It can also be used as a research reference to look at the relationship of living habits with the creation of social behavior.

The urgency of this research is that the Balinese community in Toraja tend not to focus on generating the values of the original culture in reviving the Balinese identity for the next generations so that it will greatly influence the educational behavior as Balinese human reality. The cultural blend caused by the domicile displacement has influenced the living behavior which is based on the original culture, increasingly got eroded, so it is necessary to meet the basic cultural values with the local culture that can accommodate the complete sustainability of life. 
Similar research has been conducted in relation with the Sabayan Taka Salulung philosophy that is manifestly bound in Pakraman village in Bali. The bundle of Pakraman village is bound in the context of the Balinese community. This research focuses on the Balinese community in Toraja that is detached from the Pakraman village ties, so that the new village of Pakraman is present as the local context in which the Balinese are domiciled especially in Toraja and revive the Balinese identity for the next generations. So, in terms of educational behavior as the reality of Balinese people, it especially can be read whether it still describes the integrity of Balinese local wisdom or there has been a symbiosis mutualism in a cultural blend that mutually reinforce the original culture.

\section{Literature Review}

\subsection{Structural Functionalism Robert K. Merton in the Framework of Local Wisdom}

Merton's theory of functional structuralism, mostly influenced by Durkheim. Durkheim stated that, social facts may have certain functions and he admits that some social facts are historical coincidences. Therefore, the needs of some societies can be determined by studying the society with a functionalist approach although it must be preceded by historical study. In macro-level, social facts is one of the reasons why his work has a central role in the development of structural functionalism. However, whether Durkheim is a functionalist or not, can still be debated and depends on how we define Robert K. Merton's Functionalism with Structural Functionalism Theory which asserts that on order, it ignores conflicts and changes in society. The main concepts are function, disfunction, latent function, manifest function and equilibrium. Society according to this theory, is a social system consisting of interrelated parts / elements that are united in balance. Changes that occur in one part will bring changes to the other. The basic assumption is that any structure in the social system is functionally against the other. Conversely, if it is not functional then the structure will not exist or disappear by itself. Therefore, the purpose of structuralfunctionalism studies is to build a social system, or social structure, through studying the pattern of relationships that has a function between individuals, groups, or social institutions within a society, at a certain period of time. Robert K. Merton argues that the object of sociological analysis is social facts such as social roles, institutional patterns, social processes, group organizations, social control, etc.

From the beginning Robert $\mathrm{K}$. Merton argues that Functional Structural analysis focuses on groups, organizations, societies, and cultures. He states that any object that can be used as a functional structural analysis reflects the standard (means patterned and repetitive). In addition to the main theory of Robert K. Merton's contribution is the relationship between culture, structure, and anomy. Merton defines culture as a regular "normative set of normative values that controls the behavior given equally to all members of a particular society or group, and social structure as" a series of regular social relationships "that influences a particular member of society or group in one way or another. While an anomy occurs when there is a disfunction between socially structured norms and cultural goals, and the ability of members to act according to the norms and goals (Merton 1968: 216).

Based on Merton's theory, Behavior is the essential element of all forms of cultural responsibility. All forms of life accountability are the process of entrapment. A life in any kinds of patent structure is the arena of transforming the behavior of the society when life responds to various needs, then it is increasingly revealing its importance and influence that distinguishes reaction ability and adaptation, as well as exploration of that life. Culture is a continuous wholeness of a comprehensive life, from which local wisdom is formed. 
Local wisdom is a human effort by using the common sense (cognition) to act and react to things, objects, or events that occur in a certain space. As a term, wisdom is often defined as 'judgement', wisdom is understood as a person's ability to use his or her knowledge or experience in acting or reacting as a result of judgment on something, object, or event that occurs. Local specifically refers to a limited interaction space with a limited value system. As the interaction space, it involves a pattern of relationships between human beings or human being and physical environment. Nurma Ali Ridwan, in the "Landasan Keilmuan Kearifan Lokal (Scientific foundation of Local Wisdom) ", says that substantially, local wisdom is the prevailing values in a society. The values that are believed to be true and become the reference in the daily behavior of the local community. Surasmi expressed that local wisdom can be understood as ideas, values, local views which is wise, full of wisdom, good value that are embedded and followed by members of the community. Wisdom immediately emerges, if someone opens himself to live together with the existing plural reality. Local wisdom is not just a discourse but the reality of its implementation, not just words but actions and not symbols or slogans, but a smart side to build the civilization of the Indonesian nation. It can be interpreted that the process is directly proportional to the result, the cultural behavior in society should have character that is in accordance with the noble values of the society, not only as the transfer of knowledge, but also more broadly as a culture advancement (enculturation) that is the formation of character and the character of society thoroughly, which in the future can bring a broader change.

In Balinese society the value of local wisdom that has been proven to promote life as disclosed by Wisnumurti, is the value of local wisdom Tri Hita Karana: a cosmopolitan value about the harmonization of human relations with God (sutata parhyangan), human relationships with fellow human beings (sutata pawongan) and harmonization of human relationships with the natural environment (sutata palemahan). This value is able to maintain and organize social relationship patterns in the community so it can run very dynamically. As a whole in Tri Hita Karana, the philosophy of Salunglung Sabayantaka, Paras Paros Sarpanaya affirms that the roots of a social value for the need of togetherness and equal cooperation with one another as a social unity appreciates and respects each other as an integral part in it, especially in the sutata pawongan as local wisdom (Wisnumurti, 2009: 260). This is also explained in the book, with the title "Mission, Misiologi dan Evangelisasi di Indonesia " written by Mgr. Edmund Woga, that to broader the meaning, sabayantaka salula is the existence of human beings who share the joys and sorrows, mutual love, help each other, care for each other, feel each other in the bonds of the familiar and true brotherhood, in Bali, it is usually expressed through language.

Thus interpreted from the point of educational culture, the value of local wisdom Salunglung Sabayantaka, Paras Paros Sarpanaya clearly includes a holistichumanistic educational rhythm that considers education as a process of respecting the individual dignity of the learners as entire human beings who have the needs and goals of their lives in order to realize self, and realizing all the potential capabilities to become real. (Engkoswara, 2007: 327).

\subsection{Social Identity Theory: Reading the Wholeness of Self Identity for the formation of cultural behavior}

To explain about social identity, there is a related important concept, the social category. Turner (in Tajfel, 1982) and Ellemers et al. (2002) describe social categories as dividing individuals by race, class, occupation, gender, religion, and so on. Social categories relate to social groups defined as two or more persons who perceive themselves or consider themselves as part of the same social category. An individual at the same time is a member of various 
categories and social groups (Hogg and Abrams, 1990). Categorization is a cognitive process for classifying objects and events into meaningful categories (Turner and Giles, 1985; Branscombe et al., 1993). In general, individuals divide the social world into two distinct categories - that is : We and They. We are in-groups, while they are out-groups. Based on the description of some figures about the definition of social identity, it can be concluded that social identity is part of a person's self concept derived from knowledge of membership in a particular social group, which is accompanied by values, emotions, levels of involvement, care, as well as a sense of pride in his membership in the group.

According to Koentjaraningrat, an anthropologist, because of the revolution and the social experienced change, the mental attitude stems from the cultural value system that has existed since several generations ago. A.S.Munandar asserted that the mental system varies greatly according to the cultural diversity of a particular nation. So, in discussing the mentality, the focus must be on a personal or a particular group or should pay attention to whether it is the mental of particularistic or mental of the nation (universalistic). Koentjaraningrat says that the mentality derives from the cultural value system. By using Kluckhon's framework, he reveals the existence of two major classes of mentality, that is, the mentality of urban society and the mentality of rural society. He thinks villagers work hard for eating. Villagers have a life orientation which is determined by today's life. The life of the people must be in harmony with the nature. In relation to each other, villagers judge high, the concept of equally equal taste. Mutual cooperation has a high value. This causes their attitudes to be very conformist (it is expected that people will not deliberately attempt to stand out above others). The city people (The mentality of Javanese nobility class ) assumes that human beings work for the position, power, and outward signs of prosperity. The time orientation is more determined by the past. They rely too much on fate. In relation to each other, the city people are very oriented towards the boss, and wait for blessing from above. The above description according to Koentjaraningrat is a mental attitude that has long been settled in our minds, because it affected or sourced on our cultural value system since several generations ago that conditioned in such a way that it persisted in a long span of time.

Related to culture, reading mentality can not be separated from understanding the identity of the Balinese. Identity is an expression of the cultural existence of a group. Similarly, the mentality, as revealed by Yudi Latif in the book with the title "Negara Paripurna" ( the Plenary State), said that Balinese mentality is strongly influenced by the concentric structure of Indian cosmology as seen in the way of thinking, the moral system, ceremonies and art (Yudi Latif, 2001: 14). Of course in this cultural system, Hindhu Bali community has a close relationship with the Indian culture as the origin of the development of Hinduism in Indonesia. Also similar to what is disclosed by Made Sutaba, et al that, the mentality of the Balinese is motivated by the view of life taken from religious teachings through wira carita ( story of heroism ) which are now still exist in the midst of the Balinese people (Made Sutaba, 193: 162) . As a result, cultural identity is also recorded in ethnic identity for example, It can be determined by cultural material factors, such as food, clothing, housing, equipment, and nonmaterial factors such as language, customs, beliefs, ways of thinking, attitudes, et cetera (Liliweri, 2005: 48). However, cultural identity does not come alone, but is shaped or built by a dynamic interaction between context (and history) and construct. Therefore, Maunati states that it is situational and can be changed, arranged in relation with a number of other (Maunati, 2004).

Along with this definition, then identity is formed or built through a process that continuously happened. Furthermore, identity determines the differentiation of a group with other groups in a multicultural 
society. Human identity must be seen from the interconnectedness between multidimensional, paradoxical and monopluralistic human beings with their adopted values or life guidelines. In the end, the identity of man, both individually and collectively, is determined by the combination of uniqueness that is in him with the implementation of the values that he embraces in the attitude and behavior of his life. If value is the essence of the culture expressed in the system of action and cultural artifacts, then human identity is closely related to its cultural identity.

Thus the identity of the Balinese must be discussed within the psychologicalcultural framework, that is how the Balinese culture becomes the spirit as well as the guiding attitude and behavior of the Balinese in their life, both as individuals and groups. The Balinese, in this case, are not everyone born, raised, or domiciled in Bali; nor are people using the attributes of Balinese culture; who can speak Balinese fluently; also not all people who are Hindus. The identity of the Balinese is reflected in their daily attitudes and behaviors, and their interaction in the wider society. In a global age characterized by high population mobility and more open inter-ethnic interactions, the identity of Balinese can be maintained in any space and time. Migrant communities outside Bali for example, can clearly see their Balinese identity if they continue to carry out Balinese culture in their daily lives. On the contrary, the Balinese who no longer use Balinese culture as a guide to his attitude and behavior, he has lost his identity as a Balinese. Communities in Bali are both integrated in a traditional village or Pakraman village. Pakraman village is a Balinese Hindu community organization based on the unity of the common residence area and the most fundamental religious spiritual for the relation pattern and social interaction pattern of Balinese society. Article 5 of the Provincial Regulation of Bali No. 3 of 2001 states that the Pakraman village has the following tasks: First, Creating awig-awig (village rules). Second, Managing village manners (village people). Third, Arranging the management of village property. Fourth, Conducting the development in all areas with the government, especially in the fields of religion, culture, and society. 5. Fostering and developing Balinese cultural values in order to enrich, preserve, and develop national culture in general and regional culture in particular based on "paras-paros, sagilik-saguluk, salunglung-sabayantaka "(deliberation).

Therefore, Pakraman village and its values are Balinese cultural identity, which in its implementation in each region has differences in the kala-patra village framework. The life in the Pakraman village includes the efforts of the people to gain happiness (harmony) through three harmonious relationships, namely with God (sukertaning parahyangan), with fellow human beings (sukertaning pawongan), and with nature and environment (Sukukaning palemahan). These three relationships are actually the foundation of Balinese culture, so that Balinese or Balinese people can be formulated as religious human beings, uphold brotherhood (panyamabrayan) and togetherness (paras-paros, sagiliksalunglung sabayantaka), and the ones who love nature and environment.

\section{RESEARCH RESULTS \\ 4.1 Overview of Local Wisdom of Toraja Society : Reviving the Salunglung Sabayantaka, Balinese Values of the Balinese Society in Toraja}

The Toraja Society is identical to its cultural integrity, the attachment of Toraja society to its culture is reflected in various religious rituals as well as societies. In Toraja culture, the most basic social bond is Tongkonan. Tongkonan became the integrity of the Toraja people in translating various social demands of society as custom and culture. In addition to home, Tongkonan is the center of socio-cultural life of Toraja tribe. The rituals and ceremonies associated with traditional houses always involve large 
families. Tongkonan is very important in the spiritual life of Toraja tribe. Therefore, all family members will be tied to its Tongkonan.

The life of Balinese people in Toraja certainly has a social structure as a supporting cultural unity for the implementation of various Balinese realities as well as the Balinese in Bali as their own hometown. Culture is created from the struggles of life facing the challenges of context and the need for acceptance, acknowledgment and self-achievement and group in the integrity of beliefs. Therefore, the Balinese in Toraja are required to reinterpret the self -presence in other cultural integrity. This becomes the basic principle when life must be interpreted as global unity. Each tribe has its own culture but the basic principle of culture or so called humanity, certainly has many sides in common. In Toraja, Toraja People live in the integrity of Tongkonan as the unifying center and the shaping of the human life values for Toraja people, as well as in Bali, the human life of Balinese people is strongly tied to the integrity of the Pekraman village with the various life rituals that put lives in order to achieve the goal of harmony. Both in Bali also in Toraja, human life can be likened to the ceremony. Every phase of life is always accompanied by a ceremony. In Toraja man's ceremonial system is known by the name of Rambu Tuka '(fun ceremony) and Rambu Solo' (grief ceremony). In Balinese man's ceremonial system known as Panca Mahayadnya, Those are, dewa yadnya, rsi yadnya, pitra yadnya, manusa yadmya, and bhuta yadnya, for daily (nitya karma) and even incidental (naimitika karma). Based on interviews with the father of I Made Ribawa, who affirms that the future principle of the integrity for the Balinese means the values of Salunglung Sabayantaka. He Affirmed that, Nyadnya not just a religious ceremony, more than that all human activity in order to give prostate division to Hyang Widhi is Yadnya. Basically Yadnya is a buffer of the world and the universe, because nature and humans were created by Hyang Widhi through
Yadnya. At the time of srsti that is the creation of the Hyang Whidhi in the condition of Nirguna Brahma (God in the form without nature) do meditation to make himself the Saguna Brahma (God in the nature of Purusha and Pradhana). From this preliminary process, it is clear that Yadnya's initial creation was Hyang Widhi's selfsacrifice from Nirguna Brahma to become Saguna Brahma. Furthermore all nature is created by evolution through Yadnya.

In its position as a Balinese man in the other islands, the dynamics of Panca Mahayadnya is conditioned and integrated with local culture. In this case the Pekraman village as the center of the formation, learning and practice of Balinese cultural values is no longer exist in physical form, but the integrity of the Pekraman village as the wholeness of the Balinese human self, remains present in the Balinese immigrants, but there is a possibility that the culture assimilation happened by putting the Pekraman village as the integrity of Tongkonan. The Balinese community in Toraja does not necessarily assert itself as the wholeness of the Tongkonan in physical form or directly involved in the genealogy of a family called Tongkonan, but the values maintained in the meaning of Tongkonan are integrated as the preserved values in the meaning of the Pekraman village. Therefore, the Balinese people in Toraja feel that life in Bali is not different from life in Toraja in terms of cultivating the spirit of mutual cooperation or so-called mutual help to bear the burden of life in cultural guidance or socalled local wisdom. It was stated by one of the informants, I Ketut Linggih.

Referring to the above description, it can be formulated that the Balinese in Toraja who are still Hindus or other religions such as Christian and others, still put forward their identity that was born from the identity of religiosity of Balinese man, namely Hinduism. Similar to Toraja man, Toraja identity is the integrity of his religiosity identity in aluk beliefs also in Christianity. So thus looking for the answers of the Balinese identity in Toraja in their integrity 
of the mentality of its Balinese identity, at least for those who still practice the Hindu belief, are (1) sourced from the siwa-buddha tatwa; (2) having an attachment to the three heavenly; (3) implementing the Panca Mahayad; (4) using upakara (banten) in accordance with tradition derived from Hindu scriptures and lontar in Bali; (5) in the family. It is characterized as sanggah or kemulan, the existence of sanggah or kemulan; and (6) making Hindu ethics a guide in presenting good attitude and behavior.

Thus, the Balinese in Toraja who are still in Hindu belief will certainly continue to fight for the distinctive character of his Hinduism in the family kinship of the fellow Hindu family, immigrants known as the pesamuan. The Balinese Hindu community in Toraja is not as Hindu in Bali where the pekraman village is still preserved and the temples becomes parts of their daily activity. In contrast to the Hindu Balinese worship practices in Toraja, the rituals in Hindu religiosity are very limited, and the Hindu Toraja mentioned or worn on aluk todolo is a belief born, growing and developing in Toraja. They are certainly different from the Hindu in Bali. In this case, the Balinese Hindus in Toraja, such as Mr and Mrs. Ketut Linggih, Mr. Ketut Budiana, Mr. Nyoman, Mr. Made Ribawa, carry out the worshiping activities by maximizing the family as pura or sanggah that is directly related to working on the pentaladanan life in the integrity of the belief for the community in the household and in the vicinity, although there is no sanggah in front of the house, but inside the house stands a plangkiran, a kind of sanggah or pura to worship to God, It indicates that they keep putting sanggah as the reality of their lives.

There is a kind of Balinese ties to the meaning of Balinese Hinduism which can not be maximized in Toraja, but it is still accomplished by presenting themselves as the integrity of the dynamics community life in Toraja. As Made Ribawa pointed out, that making yourself and family part of the growth for the other faiths will also naturally bring about the growth and advancement of self and family faith. Therefore Made Ribawa, has given himself in the journey of his worship to take part in the improvement of other people's faith. It is reminiscent that almost all Balinese cultural activities are associated with religious activities in the concept of ngayah. The Balinese Hindu religion in Toraja also works on the value system and norms that are implemented in the action system and social systems, and embodied in the form of great and fascinating cultural materials such as Toraja society in the culture of mantunu in the celebration of rambusolo. The Toraja people without Tongkonan are not Toraja People, Balinese without pakraman villages, Bali without temples, Bali without yadnya, Bali which has lost the hospitality of its inhabitants, are considered of losing the real Bali.

In order to establish identity and human identity in Toraja, maintaining the existence of Balinese Hinduism, becomes a very important foundation. But unlike the Balinese who are Christians or others, these Balinese Hindu values must ultimately be translated into the formation of living behavior at different levels of belief, so in this case, it seems that the Balinese Christians or other religious people in Toraja are no longer tied to the Hinduism, whereas as observations affirm about the teachings of Hinduism in the nobility of living in harmony. Based on the history of the entry of Hinduism into Bali in the past, occurred in a dialogical way so that the local cultural identity is not removed, but is honored. The Local beliefs such as life after death are embraced by the teachings of punarbhawa in Hinduism. Therefore, the Hindu religion lives and Balinese culture becomes two phenomena from one reality. The connection between the two phenomena is difficult to separate because both are present simultaneously in the cultural system of society that is tradition in customs. It means whether being realized or not, Hinduism has become the identity, even the personality of the Balinese which caused the Balinese 
culture survives in a variety of thought. Then Hindu Bali recognizes and practices the Catur, Veda Samhita, as a holy book. Hinduism as a religion consists of three basic frames, tattwa, susila, and acara. Tattwa merupakan philosophical foundation of the teachings of religion, which is derived on the siwa-buddha tattwa; susila (morality) is the foundation and moral guideline covering the doctrine of behavior (moral values and norms); and acara (events) are the habits of religious life encompassing the traditions of the activities of religious life (ceremonies and upakara). The three frameworks of the teachings can not be separated and can actually be seen in the religious activities of Hindu Balinese society in the Pakraman village which are implemented in different religious teachings, so it is important for every Balinese to interpret them as the encounter of faith in real works for humanity. In this case the echo of Balinese people who have an open attitude towards the inclusion of other cultures is real.

For the Balinese everywhere, both in Bali as well as overseas, the teachings of Bhinneka Tunggal Ika, Tatwam Asi (you are me and I am you) and Salunglung Sabayantaka, teaches about the sense of peaceful coexistence and mutual respect in ethnic diversity on the earth where they stand on, regardless of ethnic and religious differences in order to blend and suppress social inequality between ethnics

Diffusion, innovation, and development are a series of social changes, which in their applications often overlap with each other, so factually it is very difficult to distinguish. As a result, people can only feel that in reality the sociocultural system of the society in which they live has changed. They do not know for sure whether the change is due to innovation, diffusion, or because of the development process.

If we refer to the process of social change and cultural changes that occur in the life of the Balinese people, including in Toraja, it can be said that the Balinese people in Toraja is in the process of development that always make the dominant culture integrated with the original culture that leads to the achievement of harmony of good social life in thinking, acting, and reacting are always concerned with spiritual feelings, which are then articulated in the form of tolerance, teposaliro, and in the form of mutual assistance, helping each other, menyama braya, mutual care, keeping harmony between man and man, man with nature, and man with his Lord (Tri Hita Karana).

For Balinese people in Toraja, the philosophy of "salunglung sabayantaka" is not only lived by Balinese people in Bali. Local Balinese wisdom that has been firmly entrenched into a life view, has created the ability to appreciate, accept and cooperate in the concept of helping each other with everyone even in the various differences, which relates to the values of beliefs as well as culture. When the writer talks with the Balinese in Toraja, the concept of 'sagalak sagilik saguluk salunglung sabayantaka' has formed a unanimous determination facing good or bad conditions in the unity of togetherness that is interpreted as 'menyama braya' behavior which means to look at everyone like brothers, whoever they are. The values of sagalak saguluk salunglung sabayantaka are the unity of the spirit of "menyama brama" which indicates that although the Balinese have already been domiciled in various places, especially in this research, that is in Toraja, they do not lose their spirit of mutual cooperation and brotherhood.

This is the real thing about the philosophy of sagil-saguluk salulunglung sabayantaka, paras-paros sarpenaya all of which means social care for others or neighbors. In the observation of the researcher, Mr. Ketut, one of the key informants, a mathematics lecturer of at the Christian University of Indonesia in Toraja (UKI Toraja) has demonstrated the behavior of building kinship in a grief activity in Toraja. His involvement has also shown that he who is a Balinese is a family for fellow brothers of Toraja ethnic. In the grief of the late Pdt. J.A. Parenta Ranteallo's family, Mr. 
Ketut was present everyday, not as a guest but as a family doing various things in connection with the preparation process until the funeral activities of the deceased finished. Mr. Ketut was present as one of those who took part in lifting the deceased coffin to his very last resting place. When he was confirmed for his attention, he said that the deceased is a person who has contributed to his life, a very caring person, and the fruits of his love have been felt by Mr. Ketut's family. All of this, for Mr. Ketut is not an attempt to repay his merit, but is a selfsincerity based on self-meaning that can not be separated from each individual, whether in happiness or in sorrow. "I did that, and realized that I can not live without others, and I also believe that everyone is in a mutual bond." Mr. Ketut's phrase has put the Balinese people happy and prioritizes the harmony and peace in the life of the society. This became a reality that continues to be struggled for every informant in this research. In addition to the motivation to maintain the safety and welfare of living in the homeland, surely the most basic is the immigrant Balinese prioritize solidarity and peace, although it is often found that sometimes in order to promote cultural harmony, the culture of being compliant is often a solution for the Balinese people, also the ones who domicile in Toraja.

Personally, as a part of the Balinese immigrants, researchers are always trying to understand things as a whole, that for something better, to be better, it should not necessarily be at the forefront, It can also be at the back, or it can also be in middle. This is the reason why Balinese people are included in the philosophy of saguluk salulunglung sabayantaka, paras-paros sarpenaya which is more often accepting the fact and appreciating the differences for the awakening harmony, victory for every good person either directly involved or for those who are not directly involved, and also for the nature as the face of human life on this earth.

In Bali there is the term "It is Not Balinese if it is not Hindu", it is actually asserted that, the values underlying Balinese life behavior which are confirmed in the philosophy sagilik-saguluk salulunglung sabayantaka, paras-paros sarpenaya is sourced or based on the teachings of religious values, in this case is the Hindu religion. This is justified by Made Ribawa who is a civil servant teacher in SMA Negeri 1 Mengkendek ( Public Highschool 1 Mengkendek). In the integrity of himself as a person of Hindu belief bases that the behavior arises from the concept of sagiliksaguluk salulunglung sabayantaka, parasparos sarpenaya is purely dharma teaching in Hindu religious beliefs. Religious values in the Balinese society are truly fascinating in every society's life, customs becomes the binding of society to the values or norms adopted by Balinese people.

Made Ribawa is a person who keeps practicing the faith in Hindu religion but always puts forward high values of tolerance to the life around him, first his wife who also keeps faith in Christ. As a husband and wife who are different in faith, it is very difficult, but it does not require a divorce, on the contrary, based on good information from colleagues, also from some people who know Made Ribawa, like his brother-in-law, Kris Sulling Allo, affirms that, Mr. Made Ribawa 's family is very harmonious, the children are also given freedom in terms of choosing their beliefs. It is important to note that, parent's example is the first reference for the character formation of the children's life. Therefore, for Made Ribawa, Salunglung Sabayantaka is important to reinterpreted or translated in relation to different contexts and needs. Based on his colleagues in schools, both Mr. I Gede Sarjana, and also Mr. Yohanis Paliling, the figure of Made Ribawa, is a very tolerant teacher, he is also a very appreciative person and able to share life in joy and sorrow. It was proved that in his capacity as a teacher, he was also entrusted as the deputy principal of the school of Student Affairs.

On the opportunity to talk with Mr. Ketut who is watering the chili plant, tomatoes and various vegetables in his 
garden, there is a slightly unusual behavior in the views of researchers at that time, that is, he talking to the plants that are currently being treated. The language is simple, such as "grow faster, quick fruitful ". $\mathrm{He}$ emphasized that the plants that are in his garden, is a part that can not be separated from him, this is the causes of how this plants are treated differently. This condition does not happen by chance, but deep within every Balinese understands that, the love or the attitude can happen anywhere without having to be organized in human relations only. Nature, and even the invisible thing, is the part of us in which we should give the same treatment, so that the brotherhood exists (Soares \& Sudarsana, 2018).

The awareness of Balinese people in Toraja on religious values and challenges in a pluralistic society is still strong to be the basis for implementing sabyantaka salunglung. This causes Balinese people who are domiciled in other areas for long periods of time have proceed further in social community. Even though tolerance between religious communities, such as being challenged with a heavy challenge, for Balinese people, especially in Toraja, they still put forward the principle of "menyama braya" to promote brotherhood. In principle of menyama braye in Bali, it is tied to the Pekraman village. Pakraman village and its values are Balinese cultural identity, which in its implementation in each region has differences in the kala-patra village framework. The life in the Pakraman village essentially includes the efforts of the people to gain happiness (sukerta) through three harmonious relationships, namely with God (sukertaning parahyangan), with fellow human beings (sukertaning pawongan), and with nature and environment (Sukukaning palemahan). These three relationships are actually the foundation of Balinese culture, so that Balinese people can be formulated as a religious human identity, uphold the brotherhood (panyamabrayan) and togetherness (paras-paros, sagiliksalunglung sabayantaka), and who love nature and the environment. This is called the integration of the life which places Balinese people by increasing their awareness and integrity and identity as religious people, upholding brotherhood (panyamabrayan) and togetherness (parasparos, sagilik-salunglung sabayantaka), and who love the nature and the environment.

The identity of Balinese man from the perspective of custom, culture, and religion as a whole is covered in life in pakraman village. Balinese people, both individually and in groups are religious people, who prioritize brotherhood (panyamabrayan) and togetherness in diversity (paras-paros sarpanaya, sagilik saguluk salunglung sabayantaka), open to the presence of other people / ethics, and humans who desire a harmonious life, aligned, and balanced with nature and its environment.

\subsection{Measuring the Principles of Kinship, Togetherness and Wholeness in the Philosophy of Salunglung Sabayantaka}

Based on the interview data, it is noted that, the Balinese mentality is a picture or realization of Balinese identity, as well as the Balinese community in Toraja. As I Gede Sarjana, said that the Balinese mentality is first formed from the tribal identity, it is very clear when the naming of children born to intermarry as experienced by the informant, gives the child's name with the naming of the Balinese. This fact has affirmed that the identity of the community gives color to the realization of the mentality of the community. Although there are disagreements from some informants who emphasize that the name of the tribe is not at once meant to affirm the position of the Balinese mentality, only when the Balinese do not give the child's name according to the way the Balinese naming is dominantly influenced by the background of rejection of certain tribes for examples, rejection against the Balinese by other influential ethnic groups, thus hiding the identity is the mentality that is not born from the identity of the people preferring openness and harmony. 


\subsection{Name As Kinship Identity}

The Balinese have a distinctive name as a cultural unity that is structured in a color / caste system. The name in Balinese culture is recognized by all informants as the heir of tribal identity. As in other parts of Indonesia, Balinese people have a unique name as the characteristic that the person originated or descended from Bali. Here are some of the names that Balinese use by class or caste (Status of the people of the royal period), gender and birth order.

Brahmin caste is a group of religious and scientific experts. This group is most respected and usually (formerly) becomes king's advisor. Brahmin castes and their descendants got the title of Ida Bagus (for men) and Ida Ayu (for women). Their names are certain as follows: Ida Bagus Putu Tantra is sometimes abbreviated as IB Putu Tantra (Male), Ida Ayu Komang Saraswati (Female). Ida Ayu is sometimes abbreviated as Dayu as the nickname.

For the Warrior caste is a noble class of kings and royalty. This is the group that holds the power and runs the government. Warrior caste and their descendants have the title of Anak Agung (for men) and Anak Agung Ayu or Anak Agung Istri (for women). In addition there is a title Cokorda (male) and Cokorda Istri (women) are usually abbreviated Cok. Their names such as Anak Agung Raka Sidan (Male) Anak Agung Ayu Maharani or Anak Agung Istri Maharani (Female). Wesya castle is a caste of a society that has a profession as an entrepreneur, a soldier or a group of workers that produces the needs of all groups. Wesya caste has Gusti Bagus (for men) and Gusti Ayu (for women). Their names are as follows: Gusti Bagus Sidan (Male), Gusti Ayu Maharani (Female).

The Sudra Caste is an aria community and is based on ordinary people. The last caste in Balinese culture does not have a title only has a name according to the birth order ie; Wayan or Putu (first child), Made or Kadek (second child), Nyoman or Komang (third child) and Ketut (fourth child). If you have more than 4 children, then the name is reused from the first order (wayan), and so on (generally given the additional word Balik). To distinguish the sexes, the prefix in the name I (for men) and $\mathrm{Ni}$ (for women) is added.

The name for the Balinese is an identity that characterizes his mental behavior. Balinese with high, middle and low caste, have different self-esteem and acceptance. Mental is very decisive in appreciating yourself and others. Made Ribawa, understands that how powerful, how rich, how clever a person is, his/ her name can not be manipulated from the name of the Sudra caste transformed into a Brahmin caste. In the development of the Balinese community in Toraja especially in naming of their children has started to erase from the specific caste, that is Sundra caste. Some informants also named their children, no longer using the name of putu, made, nyoman, and ketut, etc., this is because that one day the name with the caste initials will get insults or rejections so that the next name of Bali generation is no longer named with the naming of Bali such as eliminating names putu, made, komang and ketut, for example Ni Komang Galuh Pertiwi, reduced to only Galuh Pertiwi.

In reviving the values of the Sabayantaka salunglung, the principle of identity will develop their mentality. The recognition and self-acceptance reflected in the name attached to one's Balinese social status has become the basis for the readiness of Balinese to build inter-ethnic kinship.

\section{4 "Menyama Braya" As the Realization of Togetherness}

The philosophy of menyama brama (feel mutual brothers) can actually be the guardian of the social solidarity of Balinese society both in Bali and overseas. The Balinese community in Toraja is strongly supported by the dominant culture of Toraja culture which is very strongly put forward the principle of brotherhood that is reflected in rambusolo and rambutuka ceremony. The 
principle that is currently awakened to the Balinese people in Toraja, is that the situation is not always the same in every person, there are local people who are so good and keep good relationship with the immigrants, but there are also the ones who do not understand even tend to be less friendly.

It is always a struggle of the Balinese people in Toraja for still prioritizing each other to greet, admonish and address, either through spoken words also through the personnel help and material in the principle of kasiturusan in Toraja. For Mr. Ketut Linggih, not only the local community fraternity, Toraja people are still maintained their spirit, such as the mutual cooperation culture in preparing for the death ceremony in rambutuka, Balinese society in Toraja also keep the consistency of welcoming life and seek brotherhood until the end of life. When The Balinese in Toraja are in difficulty or even in disability, they are still possible to give assistance to others. This is reflected in their good behavior in the neighborhood or being a good neighbour to local brothers in the overseas. They also involved in various community activities as well as providing support in the form of maintaining the values of harmony among religious people in Toraja.

Nowadays, the philosophy of menyama brama that occurs among Balinese people in Toraja is certainly not like in Bali which is reviving on with social institutions like krame subak and seke ngayah, but the fraternal values are more plural towards ethnic / ethnic diversity by putting forward the readiness to cooperate with mutual respect. It is revealed in their lives by involving themselves in various social activities in indigenous people, as well as the working community in their daily lives as workers in the community.

\section{5 "Tri Hita Karana" and "Tatwam Asi" as Principle of Wholeness}

Tri Hita Karana and Tat Twam Asi is a doctrine which is a concept to create harmony of relationship covering human relationship with God, humanity relation and human relationship with nature of its environment. "Tattwamasi" with the hope of the people, can always understand that we are all sisters "Tattwamasi kutumba tersudewa".

Tat Twam Asi means that you are me and I am you. The fundamental meaning that can be learned from Tat Twam Asi is how to love yourself as well as love other people and even the environment. Tattwamasi comes from the Sanskrit language. Tat means: it (he), Twam means: you, and Asi means: is. Tat Twam Asi is words in Hindu philosophy that teach unlimited sociality because it is known that "he is you" I am you and all beings are the same as having an atman derived from Brahman, so helping others means helping yourself and hurting people means to hurt yourself. The Implementation of Tat Twam Asi teachings can be applied in paramita chess teachings. Tat Twam Asi is a moral teaching that teaches Hinduism. The form of this teaching can be observed in the life and daily behavior of the human race concerned. On that basis, respect to each other to fellow religious believers is very necessary even to be done in good everyday life and in community life.

The Balinese community in Toraja based on the researcher's observation, Tat Twam Asi's integrated behavior in Tri Hita Karana is implemented in the Balinese human being in Toraja in its capacities as individual, social, and cultured creatures based on the religiosity of each adherent / religious person. Placing everything as part of themselves, placing the Balinese in Toraja until today, it is never involved in conflict either tribal, or even religious as well as cultural. Indeed, on the one hand, the community of Balinese in Toraja is still very few, but if it does not revive the Tat Twam Asi in life, then the conflict that begins from the case of acceptance and recognition can happen. By understanding and practicing the teachings of Tat Twam Asi, some Balinese in Toraja have different beliefs of Hinduism, but the basic principles of harmony in Tri 
hita Karana and Tat Twam Asi are still done by Balinese society in Toraja. Due to this case, It will form humans who mutually behave, feel and enable to each other.

Responding to Tat Twam Asi's principles in Christian belief as affirmed by I Gede Sarjana, that different beliefs cause the power placement for the implementation of Tat Twam Asi is no longer apply to mere cultural roots but the Spirit of Truth that is in every believer becomes a power that enables a Christian Balinese in Toraja bears the burden of others in the principle of Love. It also became an affirmation by Mr. Nyoman Wenten, that for every Balinese in Toraja regardless from different religions / beliefs, is required to show the same nobility of Balinese life in the midst of Toraja people. Therefore each belief must be the principle of the social soul of Tat Twam Asi which derived from the decency of God's guidance and not justified by the material. So good and noble behavior for fostering harmonious relationships among others who are created by God is protected continuously. In the nature and behavior of Tat Twam Asi, life will become very harmonious with one another among fellow migrants as well as among local people and migrants, especially Balinese people in Toraja can live in mutual respect, fill and peaceful.

\subsection{Focus on Actualization of Cultural Behavior of Balinese migrant Society in Toraja makes the the philosophy of Sabayan Taka Salunglun live}

Spiritual Balinese based on Hindu teachings that teach goodness, both in the principles of Karma Pala (Hinduism) and Dasa Sila (Hindu morality) permeate into family education in social control in Bali. How is the Balinese immigrants, especially in Toraja? It has been confirmed by Made Ribawa that every work and social activity in Bali has always had a relationship with religion. Neither birth, feast of joy or mourning, nor pregnant period and childbearing. Not only that, the application of the philosophy of Tri Hita Karana and
Taksu in the daily life of Balinese is an inspiration for godly personal and social life. Its implementation should make every Balinese live well with others, including in the overseas lands outside Bali. Based on the various media references, for now the praxis and life prestige of honor and high respect in relation to the Creator, the universe (country), and fellow (the nation) originally planted early in every Balinese family, in the principle of Tri Hita Karana and Tat Twam Asi apparently, is having a test in all fields. The corruption case by Jero Wacik has become an indicator of the weakening of the social soul's resilience in building this harmony of life and nature.

\section{Conclusion}

Based on the analysis of research data using qualitative analysis, based on the formulation of the research problem, it can be concluded that the narrative of the actualization of the philosophy of "Salunglung Sabayan Taka" in the living habits of the immigrants Bali Society in Toraja responds to its encounter with local wisdom, is still a basic living habit of the Balinese people even though they live in overseas, in Toraja, which is separated from Pekraman village ties in Bali, it also ties the values of each belief. The basic principles of the Sabayantaka scroll that should be bound to the integrity of the traditional village or Pekraman village have not experienced a significant change in the fulfillment of the responsibilities of life, especially in the encounter with community life and local wisdom. The Balinese community in Toraja have been working on the behavior of salunglung sabayantaka life regardless of differences in beliefs and culture. The content of these life behaviors is evident in the presence of Balinese people in providing support for various social responsibilities in Toraja, applying the example of the life of Salunglung Sabayantaka in educating the family as well as in the community. The mentality of the Balinese community in Toraja is related to the philosophy of "Salunglung Sabayantaka", in relation to the 
behavior of educating the children, measurably in placing children as an integral part of family life, society and culture. In this case the Balinese community in Toraja in terms of the mentality of educating children is still tied to the identity of Balinese identity originating from cultural values despite being in different beliefs. Boys still get more attention as the meaning of purusa in Balinese culture, boys - as a heir to the family's ancestral culture.

\section{Referencces}

Abdullah, Irwan, 2006. Konstruksi dan Reproduksi Kebudayaan, Yogyakarta: Pustaka Pelajar Abdullah.

Ahmadi, Abu. 2004, Sosiologi Pendidikan (Jakarta: Rineka Cipta.

Alo, Liliweri, 2005. Prasangka dan Konflik, Komunikasi Lintas Budaya Masyarakat Multikultur (Yogyakarta : PT. LKIS Pelangi Aksara.

Creswell, John W. 2010. Research Design, Pendekatan Kuantitatif, Kualitatif dan mixed,Yogyakarta: Pustaka Pelajar.

Engkoswara, 2007. Pendidikan Berbasis Keunggulan Lokal, dalam Ilmu dan Aplikasi Pendidikan Jakarta: UPI, Tim Pengembang Pendidikan.

Giddens, Anthony, dkk. 2004. Sosiologi Sejarah dan Berbagai Pemikirannya. Yogyakarta: Kreasi wacana.

Kartono, Kartini, 1991. Quo Vadis Tujuan Pendidikan Harus Sinkron Dengan Tujuan Manusia. Bandung: Mandar Maju.

Koentjaraningrat, 2001. Pengantar Antropologi I. Jakarta: Rineka Cipta. Koentjaraningrat.2007. Sejarah Teori Antropologi (Jakarta: Universitas indonesia, UI-Press.

Latif ,Yudi, 2001. Negara Paripurna, Historisitas, rasionalitas dan Aktualitas Pancasila, (Jakarta:Gramedia, 2001.

Liliweri, Alo. 2005. Prasangka dan Konflik, Komunikasi Lintas Budaya
Masyarakat Multikultur. Yogyakarta : PT. LKIS Pelangi Aksara.

Made Sutaba, dkk, 1983 Sejarah Perlawanan terhadap Iperialisme dan Kolonialisme di Daerah Bali, Depdikbud.

Manan, Imran. 1989. Antropologi Pendidikan Suatu Pengantar. Jakarta: Debdikbud

Maunati, Yekti. 2004. Identitas Dayak, Komodifikasi dan Politik Kebudayaan. Yogyakarta: LkiS.,2004.

Moleong, Lexy, 2000. Metode Penelitian Kualitatif. Bandung: Remaja Rosdakarya.

Pudja, G. 1982. Bhagawadgita, Jakarta:Penerbit Maya Sari, 1982.

Ridwan, Nurma Ali, 2007. "Landasan Keilmuan Kearifan Lokal", dalam Jurnal Studi Islam dan Budaya Ibda' Vol. 5 No. 1 Jan-Jun 2007, Purwekerto: P3M STAIN Purwokerto.

Robinson, Philip. 1986. Beberapa Perspektif Sosiologi Pendidikan, (Jakarta: CV. Rajawali.

Soares, F., \& Sudarsana, I. K. (2018). Religious Harmony Among Senior High School Students Multicultural Education Case Study in the CovaLima District of East Timor. Vidyottama Sanatana: International Journal of Hindu Science and Religious Studies, 2(1), 154-162.

Sopidi, 2007. Perkembangan Sikap Keagamaan: Agama dan Pengasuhan dalam Jurnal AlTarbiyah Edisi XX, Vol 1 Juni 2007.

Surasmi, Wuwuh Asrinining, 2002. Menggugah Kesadaran Guru dalam Kearifan Lokal pada Era Globalisasi. (Surabaya: UPBJJ, 2012.

Sutaba, Made dkk, 1993. Sejarah Perlawanan terhadap Iperialisme dan Kolonialisme di Daerah Bali, Depdikbud. 
Triguna, Ida Bagus Gde Yudha. 2004. Perubahan Karakter dan Penurunan Social Capital Masyarakat Bali. Orasi Ilmiah dalam rangka Dies Natalis 41 dan Wisuda 29 Universitas Hindu Indonesia.

Wisnumurti, AAGO, 2008. Elite Lokal Bali. Denpasar : Arti Foundation.
Woga, Edmund, 2009 Misi, Misiologi dan Evangelisasi di Indonesia yogyakarta: Kanisius.

Yekti. Maunati, 2004. Identitas Dayak, Komodifikasi dan Politik Kebudayaan Yogyakarta: LkiS.,2004.

Yusuf, Syamsul, 2004. Psikologi Perkembangan Anak \& Remaja (Bandung: PT. Remaja Rosdakarya. 